\title{
Transformation of a Chiral Nanoporous Bimetallic Cyano-Bridged Framework Triggered by Dehydration/Rehydration
}

\author{
Olha Sereda, ${ }^{\dagger}$ Helen Stoeckli-Evans, ${ }^{* \dagger}{ }^{\dagger}$ Oleg Dolomanov, ${ }^{\ddagger}$ Yaroslav Filinchuk, ${ }^{\S}$ and \\ Phil Pattison ${ }^{\S, \|}$
}

Institute of Physics, University of Neuchâtel, Rue Emile-Argand 11, CH-2009 Neuchâtel, Switzerland, Department of Chemistry, Durham University, Durham, DH1 3LE, U.K., Swiss Norwegian Beamlines at ESRFBP-220, 38043 Grenoble, France, and Laboratoire de Crystallographie, Ecole Polytechnique Fédéral de Lausanne, CH-1015 Lausanne, Switzerland

Received October 23, 2008; Revised Manuscript Received May 12, 2009

\begin{abstract}
The syntheses, crystal structures, and adsorption/desorption properties of two novel chiral three-dimensional cyanobridged bimetallic assemblies, $\left\{\left[\mathrm{Cu}(1 \mathrm{R}, 2 \mathrm{Rchxn})_{2}\right]_{2}\left[\mathrm{Ru}(\mathrm{CN})_{6}\right] \cdot 6 \mathrm{H}_{2} \mathrm{O}\right\}_{\infty}(\mathbf{1})$ and $\left\{\left[\mathrm{Cu}(1 \mathrm{R}, 2 \mathrm{Rchxn})_{2}\right]_{12}\left[\mathrm{Ru}(\mathrm{CN})_{6}\right]_{6} \cdot 26 \mathrm{H}_{2} \mathrm{O}\right\}_{\infty}(\mathbf{2})($ where $1 \mathrm{R}, 2 \mathrm{Rchxn}=$ trans-cyclohexane-(1R,2R)-diamine), are reported. Complex $\mathbf{1}$ crystallizes in the monoclinic space group $C 2$, with $a$ $=18.9979(11) \AA, b=17.8507(11) \AA, c=15.5853(8) \AA, \beta=119.062(4)^{\circ}, V=4619.9(4) \AA^{3}$, and $Z=4$, while 2 crystallizes in the triclinic space group $P 1$, with $a=13.7183(8) \AA, b=21.3378(12) \AA, c=24.4177(13) \AA, \alpha=68.715(4)^{\circ}, \beta=78.284(4)^{\circ}, \gamma$ $=73.004(5)^{\circ}, V=6331.3(6) \AA^{3}$, and $Z=1$. Compounds 1 and $\mathbf{2}$ can be described as nanoporous cyano-bridged frameworks, in which alternating trans- $\left[\mathrm{Cu}-\left(\text { trans- }(1 \mathrm{R}, 2 \mathrm{R}-\mathrm{chxn})_{2}\right]^{2+}\right.$ cations and $\left[\mathrm{Ru}(\mathrm{CN})_{6}\right]^{4-}$ anions are linked via $\mathrm{CN}^{-}$bridges, and have threedimensional $6^{6}$ diamondoid frameworks. In both structures there are large cavities filled with $\mathrm{H}_{2} \mathrm{O}$ molecules which show guestdependent dynamic behavior. The chemical rearrangement of the framework is driven by the loss or addition of water molecules, as proved unequivocally by single-crystal and powder X-ray diffraction analyses. These changes are also fully reversible. The two types of frameworks reported show different behavior upon drying, falling within the category of "recoverable collapsing" and "guest-induced re-formation" framework materials.
\end{abstract}

\section{Introduction}

The synthesis and characterization of coordination polymers and metal-organic frameworks (MOFs) have attracted much attention due to the variety of interesting structural topologies that can be achieved. The subject has been reviewed recently by various authors. ${ }^{1-8}$ These compounds are of great interest owing to their potential applications in the areas of gas storage, gas separation, heterogeneous catalysis, luminescence, magnetizm, conductivity, spin-transition, and nonlinear optics (NLO). ${ }^{9-21}$ The inability of many such open frameworks to support permanent porosity and to avoid collapsing in the absence of guest molecules, such as solvents, has hindered further progress in these various fields. ${ }^{22,23}$ There are a growing number of examples of stable frameworks, structurally characterized by single-crystal X-ray diffraction in both solvated and desolvated forms. ${ }^{24-28}$ Some porous metal-organic polymers have been reported to have significant cell volume changes upon guest exchange. ${ }^{27,29-31}$ Dynamic structural transformation, based on flexible porous frameworks, is one of the most interesting phenomena in coordination polymers. Recently a number of studies on such dynamic porous coordination networks have appeared. $^{32-34}$ Three types of these so-called new generation compounds have been described by Kitagawa: ${ }^{25}$ type I, the "recoverable collapsing" framework, which collapses due to the close-packing forces on removal of the guest molecules; however, it can be regenerated under the initial conditions; ${ }^{32,35-37}$ type II, the "guest-induced transformation" framework, where the structural shifts in the network are induced by the simultaneous exchange of guest molecules; ${ }^{38-40}$ type III, the "guest-

* Author to whom correspondence should be addressed. E-mail: Helen. Stoeckli-Evans@unine.ch. Tel: +41-32-7182426. Fax: +41-32-7182511.

† University of Neuchâtel.

* Durham University.

$\S$ Swiss Norwegian Beamlines at ESRFBP-220.

"Ecole Polytechnique Fédéral de Lausanne. induced re-formation", where the removal of guest molecules induces a structural change in the network, however, again it reverts to the original structure under the initial conditions. ${ }^{41,42}$ Several examples of discrete molecular assemblies have also been obtained. ${ }^{4344}$ The flexibility of coordination polymers is often incompatible with the robustness necessary for a porous framework to be maintained without the guest molecules. In this respect, cyanometalate complexes have been widely studied in many fields, mainly because of their rich and interesting structures and magnetic, catalytic, and adsorption properties. ${ }^{45-47}$ They also have the potential to form dynamic porous materials as they can adapt to changes caused by external stimuli, either within the layer or in between the layers. Such unique and novel dynamic processes in single crystals of cyano-bridged frameworks have been described. ${ }^{48}$ At the same time only a few examples of coordination polymers containing $\left[\mathrm{Ru}(\mathrm{CN})_{6}\right]^{4-}$ have been reported. ${ }^{49-52}$ On the other hand, chiral structures are a new target for such lattice architectures, chirality being an essential factor for inducing specific physical properties, for example, second harmonic generation (SHG), magnetochiral dichroism (MChD), ferroelectricity, etc. ${ }^{53-56} \mathrm{~A}$ chiral network would allow selective binding of chiral guests, and the presence of different types of metal ions could enable specific tuning of the electronic properties. A number of reports have appeared recently on new cyano-bridged bimetallic complexes, but only a small number of chiral structures have been described. ${ }^{53,57-59}$ Herein, we report on two new novel chiral cyano-bridged metal-organic frameworks with permanent porosity, based on hexacyanoruthenate (II), that show unusual guest-induced dynamic behavior. The chemical rearrangement of the framework is driven by the loss or addition of water molecules, as proved unequivocally by single-crystal and powder X-ray diffraction analyses. These changes are fully reversible and dependent on the nature of the guest. The two types of frameworks reported here show different behavior upon drying, 
falling within the category of "recoverable collapsing" (type I) and "guest-induced re-formation" (type III) frameworks.

\section{Experimental Section}

Materials. The precursor complex $\left[\mathrm{Cu}\left(\right.\right.$ trans- $\left.(1 \mathrm{R}, 2 \mathrm{R}-\mathrm{chxn})_{2}\left(\mathrm{H}_{2} \mathrm{O}\right)\right]-$ $\left(\mathrm{NO}_{3}\right)_{2}$ was prepared according to the literature method. ${ }^{60}$ All products were kept away from the light.

Preparation of $\left\{\left[\mathrm{Cu}(1 \mathrm{R}, 2 \mathrm{Rchxn})_{2}\right]_{2}\left[\mathrm{Ru}(\mathrm{CN})_{6}\right] \cdot 6 \mathrm{H}_{2} \mathrm{O}\right\}_{\infty}$ (1). To a solution of $\left[\mathrm{Cu}\right.$ (trans- $\left.(1 \mathrm{R}, 2 \mathrm{R}-\mathrm{ch} \times \mathrm{n})_{2}\left(\mathrm{H}_{2} \mathrm{O}\right)\right]\left(\mathrm{NO}_{3}\right)_{2}(125 \mathrm{mg}, 0.3 \mathrm{mmol})$ in a water/acetonitrile mixture $(1 / 140 \mathrm{~mL}) 0.1$ equiv of $\mathrm{Cu}\left(\mathrm{ClO}_{4}\right)_{2}$. $6 \mathrm{H}_{2} \mathrm{O}$ was added with continuous stirring. This was followed by the dropwise addition of an aqueous $(10 \mathrm{~mL})$ solution of $\mathrm{K}_{4}\left[\mathrm{Ru}(\mathrm{CN})_{6}\right] \cdot \mathrm{H}_{2} \mathrm{O}$ (71.91 $\mathrm{mg}, 0.17 \mathrm{mmol}$ ). The resulting blue-violet solution was kept away from the light. Dark violet crystals formed after a few days (yield $78.5 \%$ ). Elemental analysis for $\mathrm{C}_{30} \mathrm{H}_{68} \mathrm{~N}_{14} \mathrm{Ru}_{1} \mathrm{Cu}_{2} \mathrm{O}_{6}$ : found $\mathrm{C}, 37.81$; $\mathrm{H}, 6.94 ; \mathrm{N}, 19.99$; calcd C, 37.96; H, 7.22; N, 20.66\%. IR (KBr, cm $\left.{ }^{-1}\right)$ : $v(\mathrm{~N}-\mathrm{H}) 3193,3109 \mathrm{~cm}^{-1}, v(\mathrm{C}-\mathrm{H}) 2936,2856 \mathrm{~cm}^{-1}, v(\mathrm{C} \equiv \mathrm{N}) 2053$, $2083 \mathrm{~cm}^{-1}$.

Preparation of $\left\{\left[\mathrm{Cu}(1 \mathrm{R}, 2 \mathrm{Rchxn})_{2}\right]_{12}\left[\mathrm{Ru}(\mathrm{CN})_{6}\right]_{6} \cdot \mathbf{2 6 H}_{2} \mathrm{O}\right\}_{\infty}$ (2). The violet crystals of compound $\mathbf{2}$ were obtained within one week by slow diffusion of an aqueous solution of $\left[\mathrm{Cu}\right.$ (trans- $\left.(1 \mathrm{R}, 2 \mathrm{R}-\mathrm{chxn})_{2}\left(\mathrm{H}_{2} \mathrm{O}\right)\right]-$ $\left(\mathrm{NO}_{3}\right)_{2}(0.1 \mathrm{mmol}, 10 \mathrm{~mL})$ layered onto an aqueous solution of $\mathrm{K}_{4}\left[\mathrm{Ru}(\mathrm{CN})_{6}\right] \cdot \mathrm{H}_{2} \mathrm{O}(0.06 \mathrm{mmol}, 24 \mathrm{~mL}$ ) (yield 73.9\%). Elemental analysis for $\mathrm{C}_{180} \mathrm{H}_{388} \mathrm{~N}_{84} \mathrm{Ru}_{6} \mathrm{Cu}_{12} \mathrm{O}_{26}$ found C, 39.38; H, 7.01; N, 21.29; calcd C, 39.20; H, 7.09 N, 21.34\%. IR $\left(\mathrm{KBr}, \mathrm{cm}^{-1}\right): v(\mathrm{~N}-\mathrm{H}) 3221$, $3111 \mathrm{~cm}^{-1}, v(\mathrm{C}-\mathrm{H}) 2930,2857 \mathrm{~cm}^{-1}, v(\mathrm{C} \equiv \mathrm{N}) 2037,2104 \mathrm{~cm}^{-1}$.

Physical Measurements. Elemental analyses of carbon, hydrogen, and nitrogen were performed by the Microanalysis Service of the Laboratory of Pharmaceutical and Organical Propedeutical Chemistry at the University of Geneva (Geneva, Switzerland). Infrared spectra were measured using $\mathrm{KBr}$ pellets in the interval of $4000-400 \mathrm{~cm}^{-1}$ and were recorded on a Perkin-Elmer 1720X FT-IR spectrometer. Thermogravimetric (TG) analyses were carried out using a Mettler 4000 module. Samples were introduced in a closed aluminum oxide crucible and heated at a rate of $0.1{ }^{\circ} \mathrm{C} \min ^{-1}$ under nitrogen at atmospheric pressure.

X-ray Crystallography. Intensity data on violet platelike single crystals of $\mathbf{1}$ and $\mathbf{2}$ were measured using a Stoe Mark II-Imaging Plate Diffractometer System ${ }^{61}$ equipped with a graphite monochromator, using Mo K $\alpha$ radiation $(\lambda=0.71073 \AA)$ at $173 \mathrm{~K}$. The structures were solved by direct methods using the program SHELXS-97. ${ }^{62}$ The refinement and all further calculations were carried out using SHELXL97. ${ }^{62}$ The $\mathrm{H}$-atoms were included in calculated positions and treated as riding atoms using SHELXL default parameters. The non-H atoms were refined anisotropically using weighted full-matrix least-squares on $F^{2}$. The hydrogen atoms of the water molecules could not be located in difference Fourier maps. A list of $\mathrm{N}-\mathrm{H} \cdots \mathrm{O}$ and $\mathrm{N}-\mathrm{H} \cdots \mathrm{N}$ hydrogen bonds, and $\mathrm{O} \cdots \mathrm{O}$ and $\mathrm{O} \cdots \mathrm{N}$ nonbonded distances are given in Table S1 (Supporting Information). An empirical absorption correction was applied using the multiscan routine in PLATON; ${ }^{63}$ transmission factors: $T_{\min } / T_{\max }=0.483 / 0.871$ for 1 and $T_{\min } / T_{\max }=0.684 / 0.780$ for 2. Further crystallographic data and refinement details are summarized in Table 1.

Topological Analyses. The topological analyses of the 3D networks in compounds $\mathbf{1}$ and $\mathbf{2}$ were carried out using the program OLEX. ${ }^{64}$

X-ray Powder Diffraction (XPRD). X-ray powder diffraction data were collected at room temperature on a computer controlled STOESTADIP focusing powder diffractometer equipped with a curved $\mathrm{Ge}(111)$ monochromator $(\lambda=1.54051 \AA)$. A STOE linear position sensitive detector was used. The powders of samples $\mathbf{1}$ or $\mathbf{2}$ were inserted in glass capillaries of $0.5 \mathrm{~mm}$ diameter. The compounds were measured in the range of $4^{\circ} \leq 2 \theta \leq 80^{\circ}$ using a step width of $0.1^{\circ}$.

Variable Temperature Synchrotron Powder X-ray Diffraction. Variable temperature synchrotron powder diffraction measurements were carried at the Swiss Norwegian Beamlines (BM01-A) using a MAR345 Image Plate detector, $\lambda=0.724312 \AA$, capillary to image plate distance $400 \mathrm{~mm}$, exposure times $60 \mathrm{~s}, 20^{\circ}$ oscillations about $\phi$, $2 \theta$ limits $0-24^{\circ}$.

\section{Results and Discussion}

Description of the Structures. Structures 1 and 2 can be described as three-dimensional frameworks, in which alternating
Table 1. Crystallographic Data and Structure Refinement

Parameters for $\left\{\left[\mathrm{Cu}(1 \mathrm{R}, 2 \mathrm{Rch} \times n)_{2}\right]_{2}\left[\mathrm{Ru}(\mathrm{CN})_{6}\right] \cdot 6 \mathrm{H}_{2} \mathrm{O}\right\}_{\infty}(1)$ and $\left\{\left[\mathrm{Cu}(1 \mathrm{R}, 2 \mathrm{Rchxn})_{2}\right]_{12}\left[\mathrm{Ru}(\mathrm{CN})_{6}\right]_{6} \cdot 26 \mathrm{H}_{2} \mathrm{O}\right\}_{\infty}(2)$

\begin{tabular}{|c|c|c|}
\hline & 1 & 2 \\
\hline formula & $\begin{array}{l}\mathrm{C}_{30} \mathrm{H}_{56} \mathrm{Cu}_{2} \mathrm{~N}_{14} \mathrm{Ru} \cdot \\
6 \mathrm{H} 2 \mathrm{O}\end{array}$ & $\begin{array}{c}\mathrm{C}_{180} \mathrm{H}_{336} \mathrm{Cu}_{12} \mathrm{~N}_{84} \mathrm{Ru}_{6}{ }^{\circ} \\
26 \mathrm{H}_{2} \mathrm{O}\end{array}$ \\
\hline $\mathrm{fw}, \mathrm{g} / \mathrm{mol}$ & 949.12 & 5514.64 \\
\hline crystal color/habit & violet/plates & violet/plates \\
\hline $\begin{array}{l}\text { crystal size, } \mathrm{mm}^{3} \\
\text { crystal system }\end{array}$ & $\begin{array}{l}0.40 \times 0.40 \times 0.10 \\
\text { monoclinic }\end{array}$ & $\begin{array}{l}0.48 \times 0.26 \times 0.18 \\
\text { triclinic }\end{array}$ \\
\hline space group & $C 2($ No. 5$)$ & $P 1$ (No. 1$)$ \\
\hline$a, \AA$ & $18.9979(11)$ & $13.7183(8)$ \\
\hline$b, \AA$ & $17.8507(11)$ & $21.3378(12)$ \\
\hline$c, \AA$ & $15.5853(8)$ & $24.4177(13)$ \\
\hline$\alpha, \operatorname{deg}$ & 90 & $68.715(4)$ \\
\hline$\beta, \operatorname{deg}$ & $119.062(4)$ & 78.284(4) \\
\hline$\gamma, \operatorname{deg}$ & 90 & 73.004(5) \\
\hline$V, \AA^{3}$ & $4619.9(5)$ & $6331.3(6)$ \\
\hline$Z$ & 4 & 1 \\
\hline$T(\mathrm{~K})$ & $173(2)$ & $173(2)$ \\
\hline$\lambda, \AA$ & 0.71073 & 0.71073 \\
\hline$\rho_{\text {calcd }}, \mathrm{g} / \mathrm{cm}^{3}$ & 1.359 & 1.446 \\
\hline$\mu, \mathrm{mm}^{-1}$ & 1.286 & 1.403 \\
\hline measured reflns & 23973 & 61954 \\
\hline unique reflns $\left(R_{\text {int }}\right)$ & 8713 (0.0719) & $38841(0.0598)$ \\
\hline observed reflns & 7769 & 28088 \\
\hline parameters/restraints & $506 / 1$ & $2792 / 3$ \\
\hline $\mathrm{R}, 1^{a} \mathrm{wR}^{b}[I>2 \sigma(I)]$ & $0.0707,0.2075$ & $0.0446,0.0785$ \\
\hline $\mathrm{R} 1,{ }^{a} \mathrm{wR} 2^{b}$ [all data] & $0.0755,0.2153$ & $0.0756,0.0873$ \\
\hline $\mathrm{GOF}^{c}$ & 1.062 & 0.935 \\
\hline Flack parameter & $0.09(3)$ & $0.017(12)$ \\
\hline
\end{tabular}

${ }^{a} \mathrm{R} 1=\sum\left(\left\|F_{\mathrm{o}}|-| F_{\mathrm{c}}\right\|\right) / \sum\left|F_{\mathrm{o}}\right|{ }^{b}{ }^{b} \mathrm{wR} 2=\left[\left(w\left(\sum\left(\left|F_{\mathrm{o}}\right|^{2}-\left|F_{\mathrm{c}}\right|^{2}\right)^{2}\right) / \sum\left(w\left|F_{\mathrm{o}}\right|^{4}\right)\right]^{1 / 2}\right.$. ${ }^{c} \mathrm{GOF}=\left[\left(w\left(\sum\left(\left|F_{\mathrm{o}}\right|^{2}-\left|F_{\mathrm{c}}\right|^{2}\right)^{2}\right] /(n-p)^{1 / 2}\right.\right.$, where $n$ is the number of reflections, and $p$ is the number of the refined parameters.

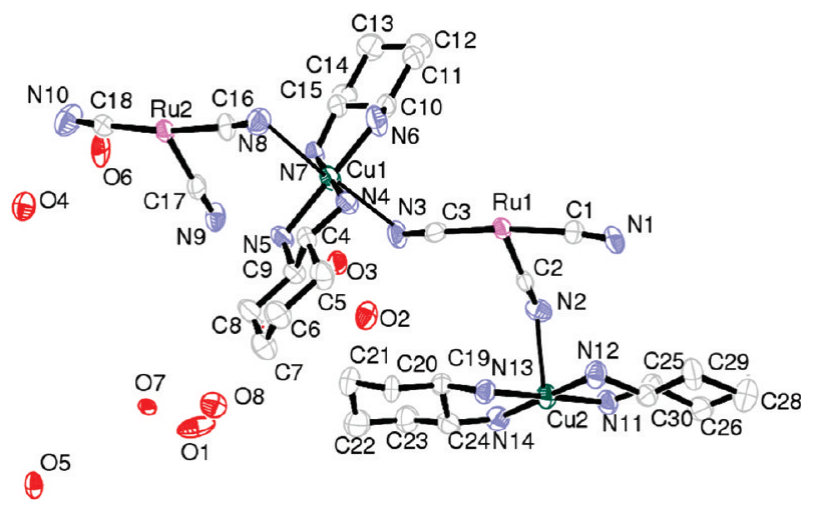

Figure 1. View of the asymmetric unit of $\mathbf{1}$, showing the numbering scheme and displacement ellipsoids at the $50 \%$ probability level. Hydrogen atoms have been omitted for clarity.

trans- $\left[\mathrm{Cu}-\left(\text { trans- }-(1 \mathrm{R}, 2 \mathrm{R}-\mathrm{chxn})_{2}\right]^{2+}\right.$ cations and $\left[\mathrm{Ru}(\mathrm{CN})_{6}\right]^{4-}$ anions are linked by $\mathrm{CN}^{-}$bridges. In both structures large cavities, filled with $\mathrm{H}_{2} \mathrm{O}$ molecules, are present.

Crystal Structure of $\left\{\left[\mathrm{Cu}(1 \mathrm{R}, 2 \mathrm{Rch} \times n)_{2}\right]_{2}\left[\mathrm{Ru}(\mathrm{CN})_{6}\right] \cdot\right.$ $\left.\mathbf{6} \mathbf{H}_{2} \mathbf{O}\right\}_{\infty}$ (1). The molecular structure of the asymmetric unit of $\mathbf{1}$ is shown in Figure 1.

Complex 1 crystallizes in the noncentrosymmetric monoclinic space group $C 2$. The asymmetric unit consists of two half $\left[\mathrm{Ru}(\mathrm{CN})_{6}\right]^{4-}$ anions, two trans- $\left[\mathrm{Cu}\left(\text { trans- }(1 \mathrm{R}, 2 \mathrm{R}-\mathrm{chxn})_{2}\right]^{2+}\right.$ cations and six water molecules. The $\mathrm{Ru}$ atoms are located on 2 -fold rotation axes. The bond lengths and angles in $\mathbf{1}$ are similar to those in $\left[\mathrm{Cu}(\mathrm{chxn})_{2}\left(\mathrm{H}_{2} \mathrm{O}\right)_{2}\right] \mathrm{Cl}_{2},{ }^{65}\left\{[\mathrm{Cu}(\mathrm{dipn})]_{3}\left[\mathrm{Ru}(\mathrm{CN})_{6}\right]\right\}-$ $\left(\mathrm{ClO}_{4}\right)_{2} \cdot 4 \mathrm{H}_{2} \mathrm{O}^{52}$ and $\mathrm{GdKRu}(\mathrm{CN})_{6} \cdot 4 \mathrm{H}_{2} \mathrm{O} .{ }^{66}$ The six-membered cyclohexane rings of the chxn ligands have trans chair-chair conformations. The $\left[\mathrm{Ru}(\mathrm{CN})_{6}\right]^{4-}$ anions have almost regular octahedral geometry with average $\mathrm{Ru}-\mathrm{C}$ bond distances of $2.035(11) \AA$ and average $\mathrm{C} \equiv \mathrm{N}$ bond distance of 1.159(15) $\AA$. 

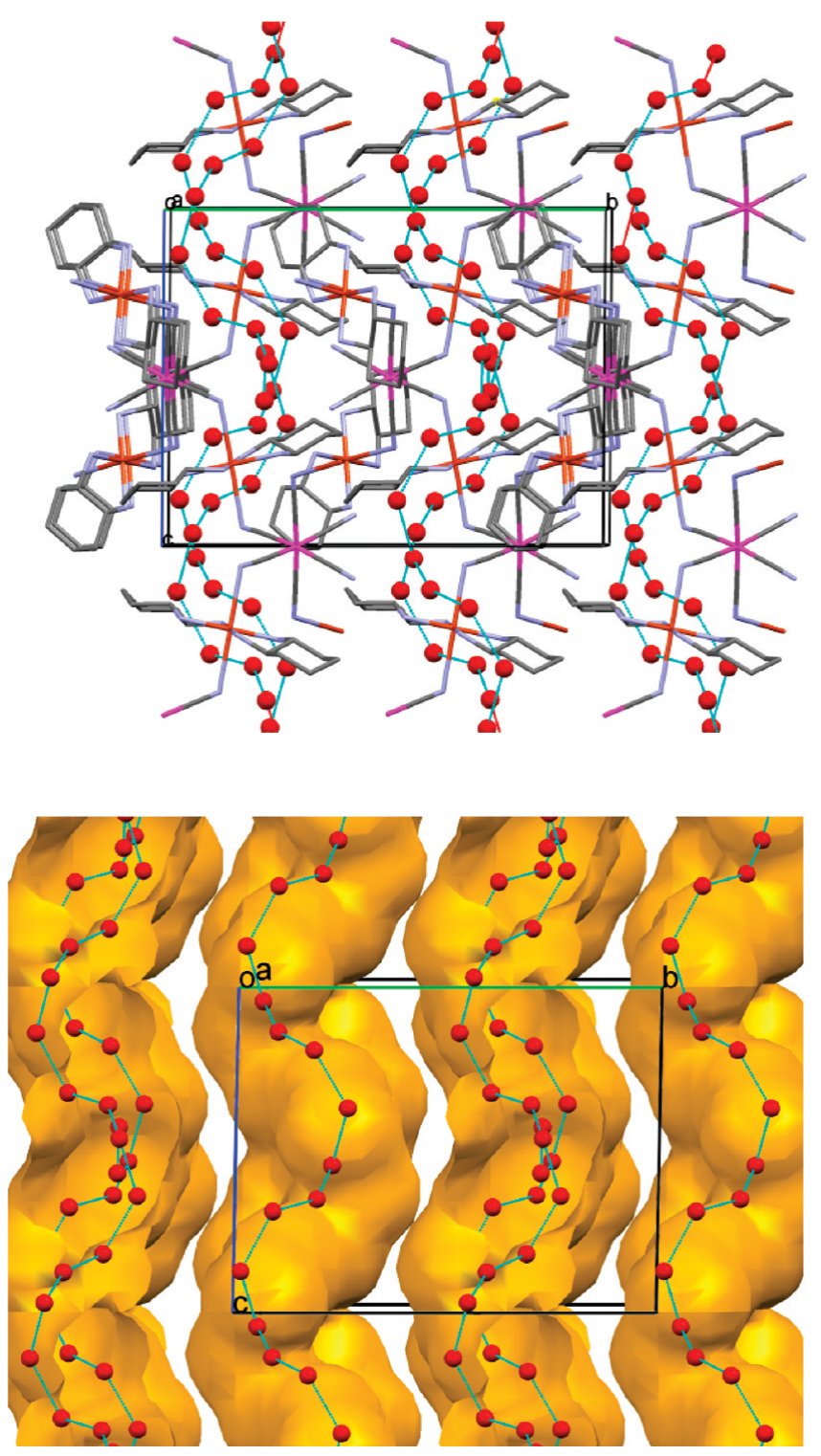

Figure 2. Top: Crystal packing of complex 1, viewed along the $a$ axis, showing the water $\mathrm{O} \cdots \mathrm{O}$ contacts as pale-blue lines (copper, orange; ruthenium, pink; oxygen, red; the hydrogen atoms have been omitted for clarity). Bottom: The framework surface showing the channels occupied by the chains of water molecules.

The ruthenium ions are linked to four copper(II) ions by four cyanide bridges, while each copper ion is linked to two equivalent ruthenium(II) ions. The solvent-accessible voids in the framework, in the absence of the water molecules, is estimated to be ca. $25.7 \%$ of the volume of the unit cell. ${ }^{63}$ The water molecules in the channels form chains as shown in Figure 2 (see also Figure S1 in the Supporting Information).

The two nonequivalent copper(II) ions (Cu1 and $\mathrm{Cu} 2$ ) exhibit octahedral CuN6 coordination geometry, involving four nitrogen atoms of the trans-(1R,2R-chxn) ligands (N4, N5, N6, N7 for $\mathrm{Cu} 1$ and $\mathrm{N} 11, \mathrm{~N} 12, \mathrm{~N} 3, \mathrm{~N} 14$ for $\mathrm{Cu} 2)$ and two nitrogen atoms of the cyano groups (N3, N8 for $\mathrm{Cu} 1$ and $\mathrm{N} 2, \mathrm{~N} 9$ for $\mathrm{Cu} 2$ ). The average value of the $\mathrm{Cu}-\mathrm{N} \equiv \mathrm{C}$ angles is $110.01(7)^{\circ}$. The axial $\mathrm{Cu}-\mathrm{N}$ bonds are long, varying between 2.482(9) and 2.614(8) $\AA$, while the average equatorial $\mathrm{Cu}-\mathrm{N}$ bond distance is $2.014(10) \AA$. This shows that both copper(II) atoms have a pseudo-Jahn-Teller distortion, ${ }^{67}$ as shown in Figure 3.

Using the conventional index of Jahn-Teller distortion, $T$ $[=$ the ratio of average value of the equatorial $\mathrm{Cu}-\mathrm{N}$ bond
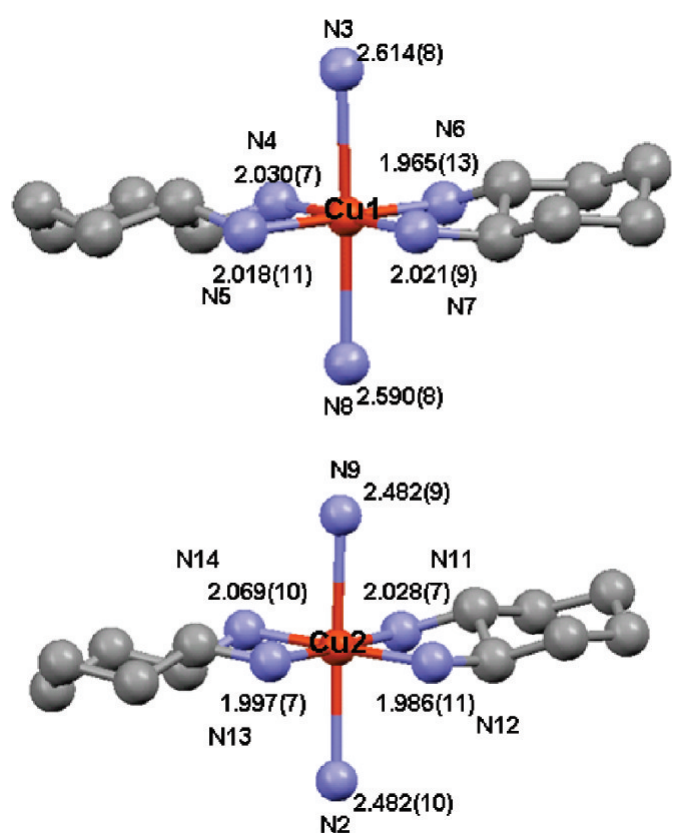

Figure 3. $\mathrm{Cu}-\mathrm{N}$ bond lengths $(\AA)$ for complex 1, showing the Jahn-Teller effect.

distances to the value of the axial $\mathrm{Cu}-\mathrm{N}$ bond distance], ${ }^{68}$ the degree of distortion of the axial bonds $\mathrm{Cu} 1-\mathrm{N} 3$ and $\mathrm{Cu} 2-\mathrm{N} 2$ was found to be 0.764 and 0.825 , respectively. For bonds $\mathrm{Cu} 1-\mathrm{N} 8$ and $\mathrm{Cu} 2-\mathrm{N} 9$ the $T$ values are 0.779 and 1.010, respectively. To date the longest $\mathrm{Cu}-\mathrm{N}$ distances reported are $2.902 \AA$ in $\left[\mathrm{Cu}(\mathrm{L}) \mathrm{Fe}(\mathrm{CN})_{5}(\mathrm{NO})\right]$ (where $\mathrm{L}=1,8$-bis(2-hydroxyethyl)-1,3,6,8,10,13-hexaazacyclo-tetradecane ${ }^{69}$ with a $\mathrm{Cu}-\mathrm{N} \equiv \mathrm{C}$ bond angle of $133.89^{\circ}$, and $2.827 \AA$ in $\left[\mathrm{Cu}(\mathrm{tn})_{2}\right]-$ $\left[\mathrm{Ni}(\mathrm{CN})_{4}\right] \cdot \mathrm{H}_{2} \mathrm{O}$ (where tn $=1,3$-diaminopropane $)^{70}$ with a $\mathrm{Cu}-\mathrm{N} \equiv \mathrm{C}$ bond angle of $115.35^{\circ}$.

Topological Analysis of Compound 1. The connectivity analysis of compound 1 shows that both $\left[\mathrm{Ru}(\mathrm{CN})_{6}\right]^{4-}$ centers have the same coordination mode. If the $\mathrm{Cu}-\mathrm{N}$ distances are limited to $2.5 \AA$, the resulting structure is represented by a onedimensional polymer chain running along the $a+c$ crystallographic direction (Figure 4).

Considering longer $\mathrm{Cu}-\mathrm{N}$ distances (up to $2.7 \AA$ ), the topological framework of $\mathbf{1}$ transforms into a three-dimensional, $6^{6},{ }^{71,72}$ diamondoid framework, (vertex symbol: ${ }^{73} 6_{2} 6_{2} 6_{2} 6_{2} 6_{2} 6_{2}$ ), see Figure 5. The framework is constructed by two ruthenium nodes, which have the same connectivity, and any two $\left[\mathrm{Ru}(\mathrm{CN})_{6}\right]^{4-}$ centers are linked by a single copper entity.

Crystal Structure of $\left\{\left[\mathrm{Cu}(1 \mathrm{R}, 2 \mathrm{Rchxn})_{2}\right]_{12}\left[\mathrm{Ru}(\mathrm{CN})_{6}\right]_{6} \cdot\right.$ $\left.\mathbf{2 6} \mathrm{H}_{2} \mathbf{O}\right\}_{\infty}$ (2). Compound 2, which was prepared by a different method from compound $\mathbf{1}$ (see Experimental Section), crystallizes in the non-centrosymmetric triclinic space group $P 1$. This structure can be described as layers of large cyclic units, in which alternating $\left[\mathrm{Cu}\left(\text { trans- }(1 \mathrm{R}, 2 \mathrm{R}-\mathrm{chxn})_{2}\right]^{2+}\right.$ cations and $\left[\mathrm{Ru}(\mathrm{CN})_{6}\right]^{4-}$ anions are linked by $\mathrm{CN}^{-}$bridges (Figure 6).

The structure is composed of six independent ruthenium atoms, twelve independent copper(II) atoms and 26 water molecules of crystallization. Five of the copper(II) atoms (Cu3, $\mathrm{Cu} 5, \mathrm{Cu} 6, \mathrm{Cu} 8, \mathrm{Cu} 12)$ can be considered to be pentacoordinate, while the other seven ( $\mathrm{Cu} 1, \mathrm{Cu} 2, \mathrm{Cu} 4, \mathrm{Cu} 7, \mathrm{Cu} 9, \mathrm{Cu} 10, \mathrm{Cu} 11)$ are hexacoordinated (Table 2). The $\mathrm{Cu}-\mathrm{N}$ bond distances in the basal or equatorial planes vary from 1.99(1) to 2.053(9) $\AA$. The pentacoordinated copper atoms have apical $\mathrm{Cu}-\mathrm{N}$ (cyano) bond lengths varying between $2.259(10)-2.513(12) \AA$. On the opposite side of the basal plane the nearest $\mathrm{N}$ (cyano) atoms are 


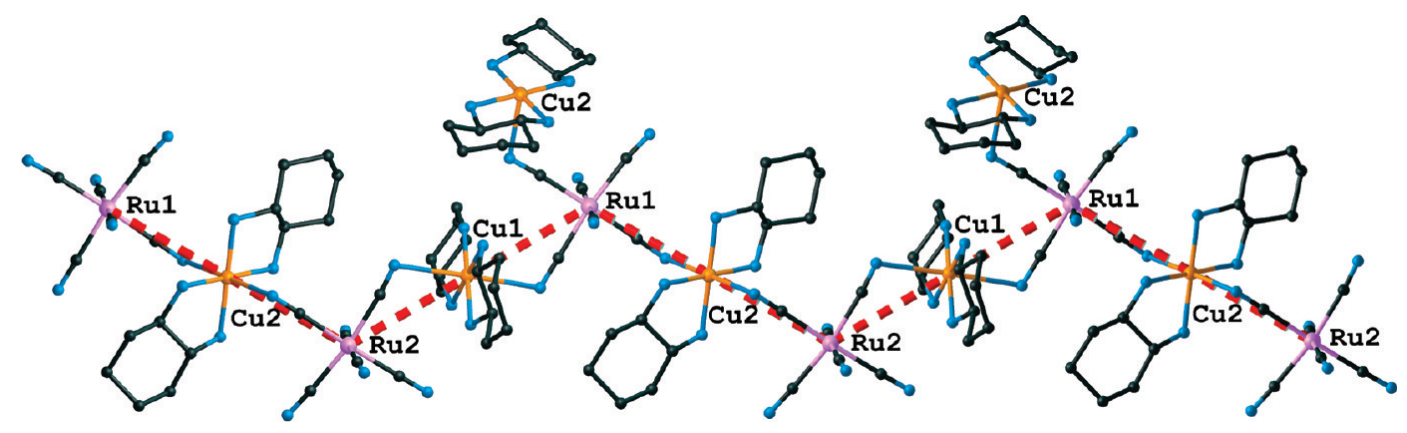

Figure 4. View of an infinite zigzag chain of 1 running along the $(a+c)$ direction. The topological connectivity is shown by stippled lines. Each ruthenium center is linked to another one by a single copper entity.

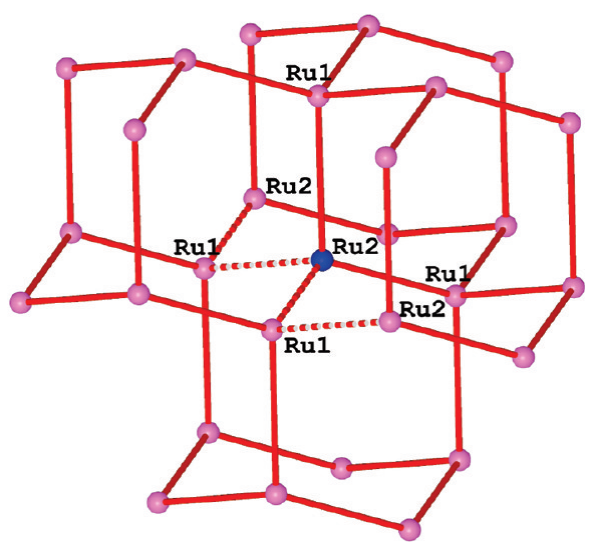

Figure 5. View of a fragment of the topological framework of compound $\mathbf{1}$, showing the topological environment of atom Ru2 (shown in blue in the center); the stippled bonds represent the zigzag chain shown in Figure 4.

at distances varying between 2.87(1) and 3.57(1) A. For the hexacoordinated copper atoms the axial $\mathrm{Cu}-\mathrm{N}$ (cyano) bond lengths vary between 2.512(9) and 2.797(10) $\AA$. The longest axial $\mathrm{Cu}-\mathrm{N}$ (cyano) bond distance reported to date is 2.539(1) $\AA$ in complex $\left\{\left[\mathrm{Cu}(\mathrm{en})_{2}\right]_{3}\left[\mathrm{Ru}_{2} \mathrm{~N}(\mathrm{CN})_{10}\right] \cdot \mathrm{ClO}_{4}\right\}_{n}$ (where en $=$ 1,2-ethylendiamine). ${ }^{74}$ The existence of extremely long $\mathrm{Cu}-\mathrm{N}$ bonds has been attributed to the coexistence of pseudoJahn-Teller elongation and electrostatic interactions. ${ }^{75}$ Here the Jahn-Teller distortion indices, $T$, vary from 0.718 to 0.878 (Table 2). The average $\mathrm{Ru}-\mathrm{C}$ and $\mathrm{C} \equiv \mathrm{N}$ bond lengths of 2.041(12) $\AA$ and 1.1159(14) $\AA$, respectively, are similar to those observed in compound $\mathbf{1}$. Four of the $\left[\mathrm{Ru}(\mathrm{CN})_{6}\right]^{4-}$ anions are involved in four $\mathrm{Ru}-\mathrm{CN}-\mathrm{Cu}$ bridges, while two $\left[\mathrm{Ru}(\mathrm{CN})_{6}\right]^{4-}$ anions are involved in only three $\mathrm{Ru}-\mathrm{CN}-\mathrm{Cu}$ bridges. It can also be seen that the Ru1-C2 $\equiv \mathrm{N} 2$ and the Ru4 $-\mathrm{C} 19 \equiv \mathrm{N} 11$

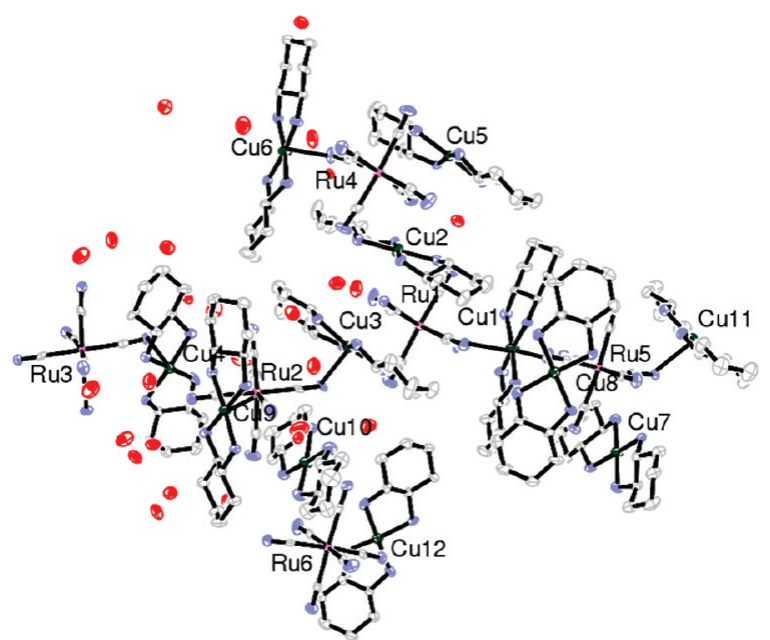

Figure 6. View of the asymmetric unit of $\mathbf{2}$, showing the metal atom numbering scheme and displacement ellipsoids at the $50 \%$ probability level. Hydrogen atoms have been omitted for clarity.

cyano groups are involved in unusual bifurcated bonds with copper atoms $\mathrm{Cu} 2 / \mathrm{Cu} 3$ for the former, and $\mathrm{Cu} 5 / \mathrm{Cu} 2$ for the latter. The corresponding $\mathrm{Cu} \cdots \mathrm{Cu}$ distances are shorter by $\sim 1$ $\AA$ compared to the other nearest $\mathrm{Cu} \cdots \mathrm{Cu}$ distances. To our knowledge this a rare occurrence of bifurcated cyano bonds in cyano-bridged complexes, although recently Rodriguez-Hernandez et al. have analyzed their presence in Prussian Blue type compounds. $^{76}$

In compounds $\mathbf{1}$ and $\mathbf{2}$ there are a number of nonlinear $\mathrm{Cu}-\mathrm{N} \equiv \mathrm{C}$ bond angles. In compound $\mathbf{2}$ there are only two $\mathrm{Cu}-\mathrm{N} \equiv \mathrm{C}$ angles which can be described as normal $[\mathrm{Cu} 5-\mathrm{N} 10 \equiv \mathrm{C} 18$ is $133.5(9)^{\circ}$, and $\mathrm{Cu} 3-\mathrm{N} 7 \equiv \mathrm{C} 15$ is $\left.131.0(9)^{\circ}\right]$ when compared to the values commonly observed in copper-containing compounds (Figure S2 in the Supporting Information). The other

Table 2. Selected $\mathrm{Cu}-\mathrm{N}$ Bond Distances $(\AA)$ and Jahn-Teller Distortion Indices, $T,{ }^{a}$ of the Copper(II) Atoms in Complex 2

\begin{tabular}{|c|c|c|c|c|c|c|}
\hline bond, $\AA^{\prime}$ & $\mathrm{Cu} 1$ & $\mathrm{Cu} 2$ & $\mathrm{Cu} 3$ & $\mathrm{Cu} 4$ & $\mathrm{Cu} 5$ & $\mathrm{Cu} 6$ \\
\hline \multirow{2}{*}{$\mathrm{Cu}-\mathrm{N}_{\text {cyano }}$} & $\mathrm{N} 27=2.690(10)$ & $\mathrm{N} 2=2.295(11)$ & $\mathrm{N} 7=2.303(10)$ & $\mathrm{N} 8=2.568(9)$ & $\mathrm{N} 10=2.259(10)$ & $\mathrm{N} 12=2.513(12)$ \\
\hline & $\mathrm{N} 1=2.743(11)$ & $\mathrm{N} 11=2.545(11)$ & $\mathrm{N} 2=2.87(1)]$ & $\mathrm{N} 9=2.685(11)$ & {$[\mathrm{N} 11=2.91(1)]$} & {$[\mathrm{N} 66=3.08(1)]$} \\
\hline \multirow{2}{*}{$\begin{array}{l}\mathrm{Cu}-\mathrm{N}_{\text {chxn }} \\
T\end{array}$} & $2.010(8)$ & $2.015(9)$ & $2.019(9)$ & $2.016(9)$ & $2.036(9)$ & $2.022(8)$ \\
\hline & 0.733 & 0.792 & & 0.751 & & \\
\hline bond, $\AA^{\prime}$ & $\mathrm{Cu} 7$ & $\mathrm{Cu} 8$ & $\mathrm{Cu} 9$ & $\mathrm{Cu} 10$ & $\mathrm{Cu} 11$ & $\mathrm{Cu} 12$ \\
\hline \multirow{3}{*}{$\begin{array}{l}\mathrm{Cu}-\mathrm{N}_{\text {chxn }} \\
T\end{array}$} & $2.008(9)$ & $2.022(9)$ & $2.024(7)$ & $2.025(9)$ & $2.021(9)$ & $2.016(9)$ \\
\hline & 0.798 & & 0.806 & 0.788 & 0.796 & \\
\hline & 0.718 & & 0.752 & 0.724 & 0.774 & \\
\hline
\end{tabular}

${ }^{a} T$ : conventional index of Jahn-Teller distortion $=$ average equatorial $\mathrm{Cu}-\mathrm{N}$ bond distance/axial $\mathrm{Cu}-\mathrm{N}$ bond distance. 

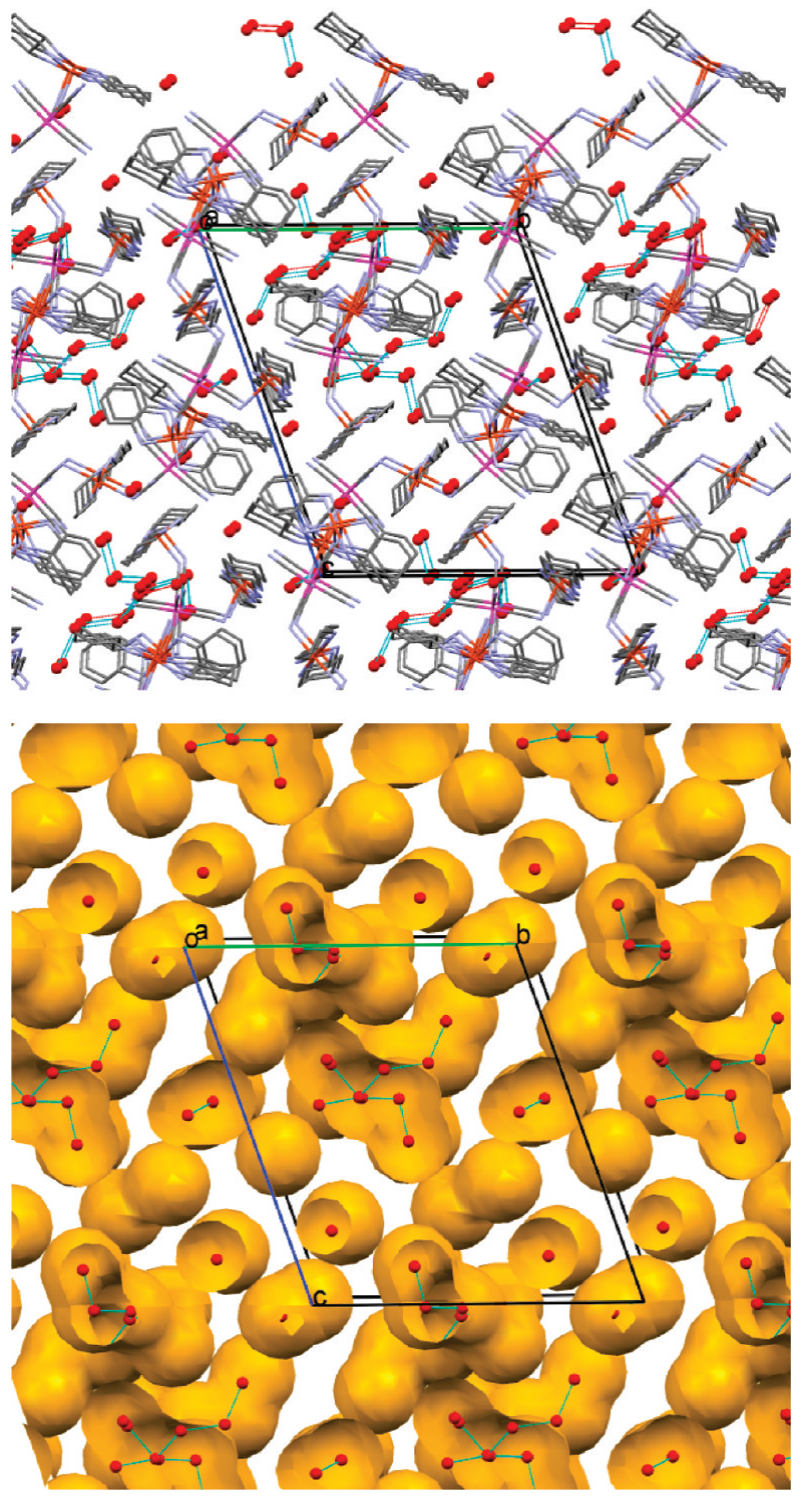

Figure 7. Top: Crystal packing of complex 2, viewed along the $a$ axis, showing the water $\mathrm{O} \cdots \mathrm{O}$ contacts as pale-blue lines (copper, orange; ruthenium, pink; oxygen, red; the hydrogen atoms have been omitted for clarity). Bottom: The framework surface showing the cavities occupied by the hydrogen bonded water molecules.

$\mathrm{Cu}-\mathrm{N} \equiv \mathrm{C}$ angles vary from $94.2(9)$ to $120.2(9)^{\circ}$ (Table S2 in the Supporting Information). Both the valence bond and molecular orbital descriptions of the $\mathrm{M}^{\prime}-\mathrm{N} \equiv \mathrm{C}$ system indicate

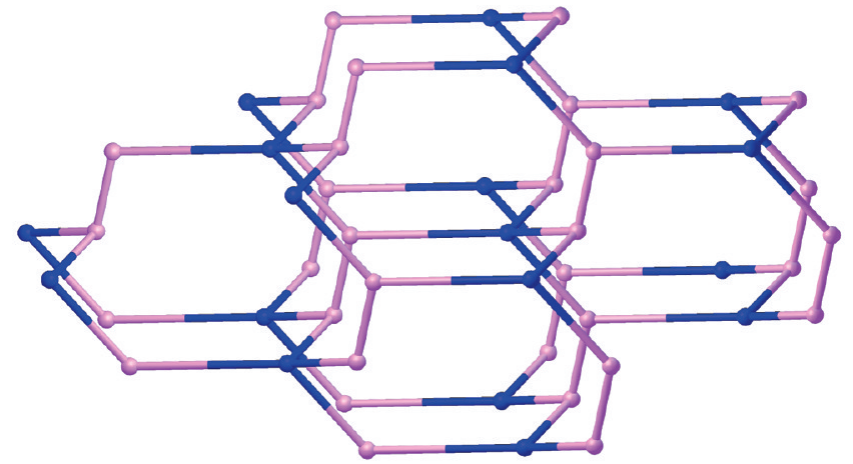

Figure 9. View of a segment of the $\left(8^{3}\right)_{2}\left(8^{6}\right)$ topological framework of compound 2 , constructed using $\mathrm{Cu}-\mathrm{N}$ interactions up to $2.87 \AA$. Ru2 is shown in blue, and Ru3 and Ru5 are shown in pink. The zigzag chain in Figure 8 is shown here in pink.

that the $\mathrm{M}^{\prime}-\mathrm{N}$ bond should be collinear with the triple $\mathrm{N} \equiv \mathrm{C}$ bond. ${ }^{77}$ This situation holds for most of the $\mathrm{CN}$ bridges observed to date, although a few compounds with angles of ca. $140^{\circ}$ have been reported. For example, in $\left[\left\{\mathrm{Cu}(\text { dien })_{2} \mathrm{Fe}(\mathrm{CN})_{6}\right\}_{n}\right]$ $\left[\mathrm{Cu}\left(\mathrm{H}_{2} \mathrm{O}\right)(\text { dien }) \mathrm{Fe}(\mathrm{CN})_{6}\right]_{n} \cdot 4 n \mathrm{H}_{2} \mathrm{O}$ the $\mathrm{Cu}-\mathrm{N} \equiv \mathrm{C}$ angles are 139 and $140^{\circ}$, with corresponding $\mathrm{Cu}-\mathrm{N}$ distances of 2.32(1) and 2.31(1) $\AA$, respectively, ${ }^{78}$ and in $\left[\{\mathrm{Cu}(\mathrm{tn})\}_{3}\left\{\mathrm{Co}(\mathrm{CN})_{6}\right\}_{2}\right] \cdot 3 \mathrm{H}_{2} \mathrm{O}$, one of the $\mathrm{Cu}-\mathrm{N} \equiv \mathrm{C}$ angles is $140.7(4)^{\circ}$ with a $\mathrm{Cu}-\mathrm{N}$ distance of $2.617(5) \AA{ }^{47}$ The nonlinearity in the $\mathrm{M}^{\prime}-\mathrm{O} \equiv \mathrm{C}-$ fragment has been explained on the basis of two valence bond structures, ${ }^{77}$ and since $\mathrm{Cu}-\mathrm{N} \equiv \mathrm{C}-$ is an isoelectronic system, a similar explanation can be applied here, as a first approximation (Figure S3 in the Supporting Information).

The solvent-accessible voids in the framework of compound $\mathbf{2}$, in the absence of the water molecules, is estimated to be ca. $11.4 \%$ of the volume of the unit cell. ${ }^{63}$ The water molecules in the voids form clusters, as shown in Figure 7 (see also Figure S4 in the Supporting Information).

Topological Analysis of Compound 2. The connectivity analysis of 2, considering covalent bonds, shows that there are three coordination modes among the six $\left[\mathrm{Ru}(\mathrm{CN})_{6}\right]^{4-}$ entities. The Ru1 entity is not attached to anything, the Ru2 entity is attached to three $\mathrm{Cu}$ entities and the rest is attached to two $\mathrm{Cu}$ entities. This difference in the coordination modes can be explained by the competition between the coordination and the hydrogen bonding to the $\mathrm{NC}-\mathrm{Ru}$ units, as well as by the steric effect caused by the bulky $\mathrm{Cu}$ entities.

The topological framework of 2 , constructed exploiting the $\mathrm{Cu}-\mathrm{N}$ contacts up to $2.7 \AA$, represents $1 \mathrm{D}$ zigzag chains running along the crystallographic $a$ direction, as shown in

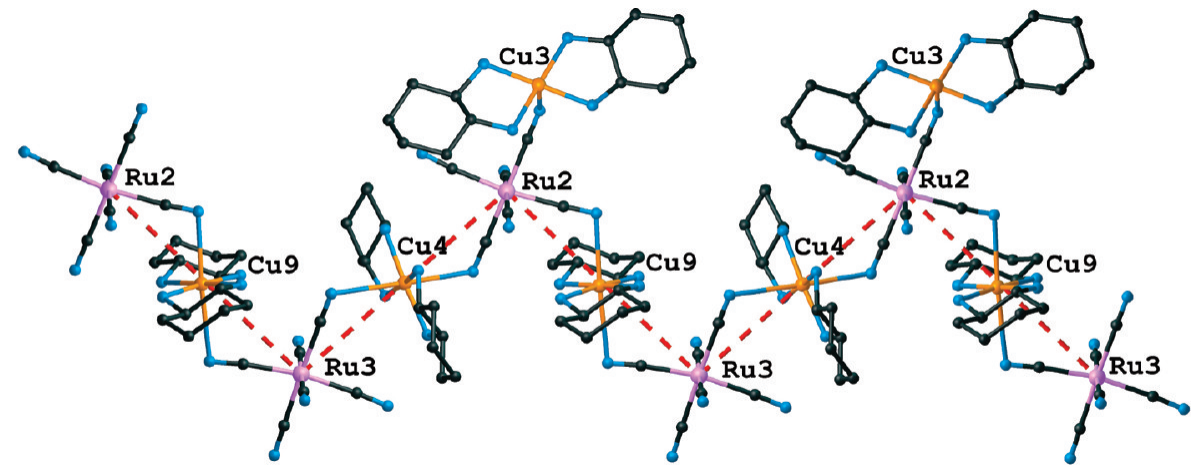

Figure 8. View of the infinite zigzag chains running along the crystallographic $a$ axis for compound $\mathbf{2}$. The topological connectivity is shown by stippled lines. 

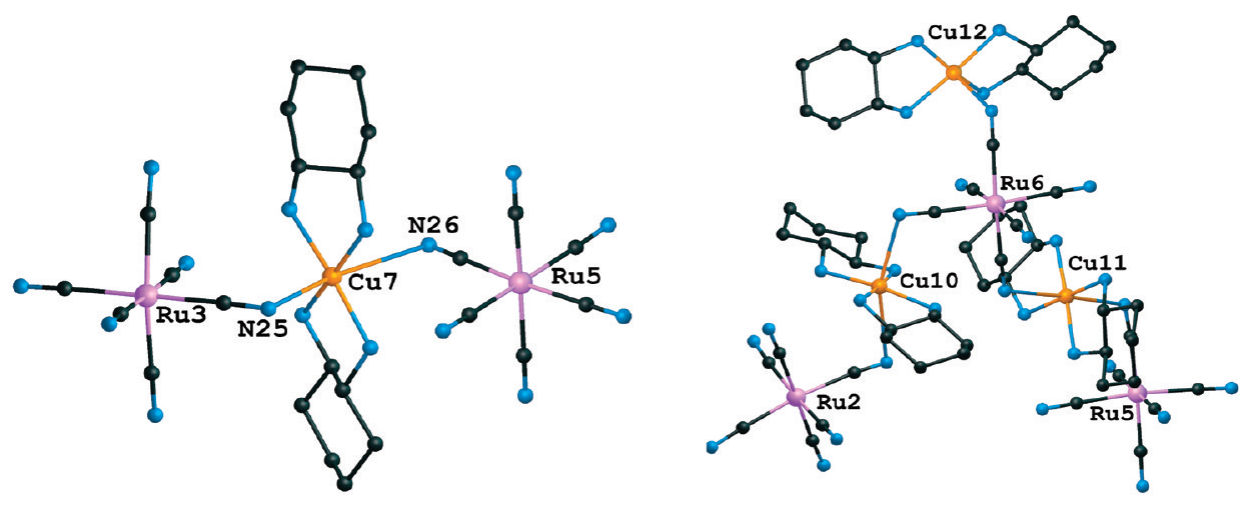

Figure 10. View of the links between Ru5 and Ru3 (left), and Ru5 and Ru2 (right) in compound 2.

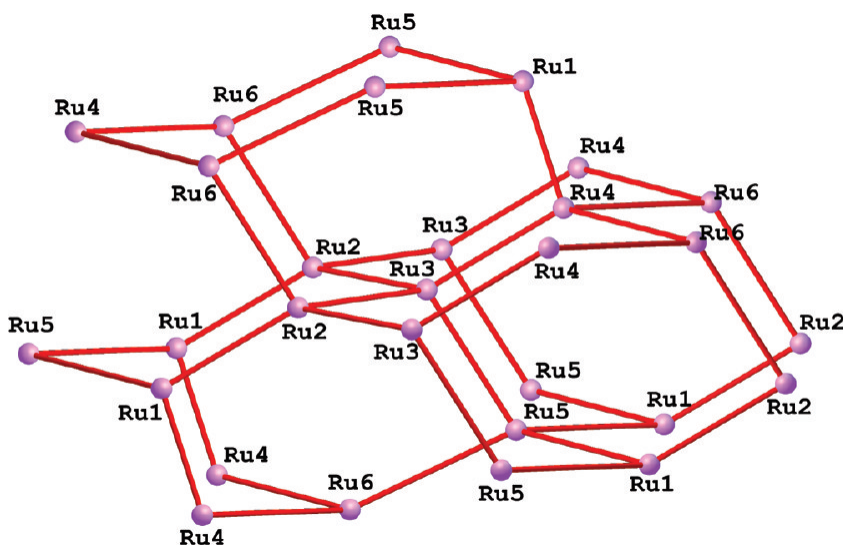

Figure 11. View of the $6^{6}$, diamondoid topological framework of compound 2 , constructed using $\mathrm{Cu}-\mathrm{N}$ interactions up to $3.60 \AA$.

Figure 8, and resembles the arrangement shown in Figure 4 for compound $\mathbf{1}$.

These chains interact through the weaker $\mathrm{Cu}-\mathrm{N}$ (cyano) interactions, at first forming two-dimensional $6^{3}$ honeycomb layers constructed from $\mathrm{Ru} 2$ and $\mathrm{Ru} 3$ nodes (interactions up to $2.87 \AA$ ), and then, with interactions up to $2.91 \AA$, a more complex three-dimensional framework with two three-connected (Ru3, Ru5, vertex symbol $8_{4} 8_{4} 8_{4}$ ) and one four-connected (Ru2, vertex symbol $8_{2} 8_{2} 8_{2} 8_{3} 8_{3} 8_{3}$ ) network nodes (Figure 9).

Atoms Ru3 and Ru2 form zigzag chains as shown in Figure 8. Ru5 and Ru3 are connected through a single $\mathrm{Cu} 7$-entity link; the two similar links between Ru2 and Ru5 are supported by $\mathrm{Cu} 11, \mathrm{Ru} 6$ and $\mathrm{Cu} 10$ or $\mathrm{Cu} 1, \mathrm{Ru} 1$ and $\mathrm{Cu} 3$ entities (Figure 10).

Consideration of the $\mathrm{Cu}-\mathrm{N}$ interactions in the range up to $3.60 \AA$ leads to a complex three-dimensional framework with six ruthenium and two nitrogen nodes (N2 and N11, which are connected and each binds to two $\mathrm{Cu}$ entities). Reconstruction of this network, considering only the $\left[\mathrm{Ru}(\mathrm{CN})_{6}\right]^{4-}$ units and replacing the $\mathrm{Cu}_{2} \mathrm{~N}-\mathrm{NCu}_{2}$ entities by a link, produces a $6^{6}$ diamondoid framework, in which all the ruthenium nodes have equivalent connectivity (Figure 11).

Thus, on considering longer $\mathrm{Cu}-\mathrm{N}$ interactions it can be seen that compounds $\mathbf{1}$ and $\mathbf{2}$ have the same topological network and are closely related. The difference in the crystal structures appears to be due to the manner in which the guest water molecules order in the host frameworks.

IR and CD Spectroscopies. The IR spectra shows two sharp $v_{\mathrm{CN}}$ bands at 2053 and $2083 \mathrm{~cm}^{-1}$ for $\mathbf{1}$ and 2037 and 2104 $\mathrm{cm}^{-1}$ for 2 , indicating the existence of two types of cyanide groups in the crystal lattice. The lower frequency band corre-

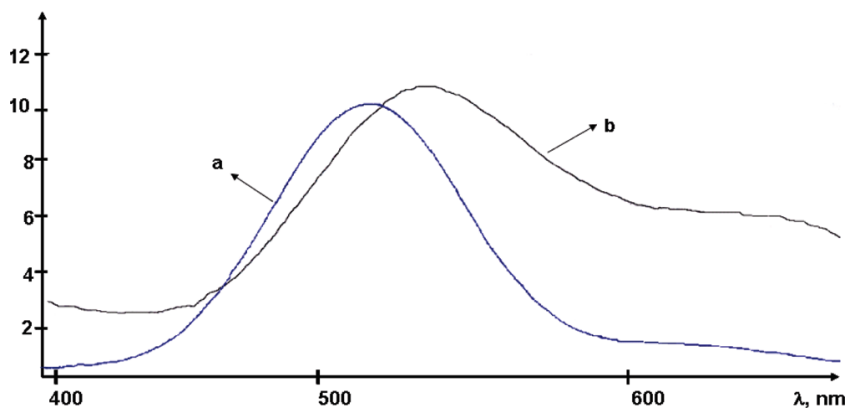

Figure 12. CD spectra of (a) an acetonitrile-water solution of the bischelated precursor $\left[\mathrm{Cu}(\text { trans- }(1 R, 2 R)-\mathrm{chxn})_{2}\left(\mathrm{H}_{2} \mathrm{O}\right)_{2}\right]\left(\mathrm{NO}_{3}\right)_{2}$, and (b) a powder sample of $\left\{\left[\mathrm{Cu}(1 \mathrm{R}, 2 \mathrm{Rchxn})_{2}\right]_{2}\left[\mathrm{Ru}(\mathrm{CN})_{6}\right] \cdot 6 \mathrm{H}_{2} \mathrm{O}\right\}_{\infty}(\mathbf{1})$ in a $\mathrm{KBr}$ matrix.

sponds to that of $\mathrm{K}_{4}\left[\mathrm{Ru}(\mathrm{CN})_{6}\right] \cdot 1 \mathrm{H}_{2} \mathrm{O}$ and can be ascribed to a nonbridging cyanide group. The higher frequency band is attributed to the bridging cyanide group. ${ }^{51,79}$

Circular dichroism measurements (Figure 12) were used to establish the enantiomeric character of the coordination polymers (solid state, using $\mathrm{KBr}$ discs) and $[\mathrm{Cu}($ trans- $(1 R, 2 R)$ chxn $\left.)_{2}\left(\mathrm{H}_{2} \mathrm{O}\right)_{2}\right]\left(\mathrm{NO}_{3}\right)_{2}$ (in solution). The enantiopure bis-chelated precursor shows a positive Cotton effect at $\lambda=513 \mathrm{~nm}$, and compound 1 exhibits a positive Cotton effect at $\lambda=560 \mathrm{~nm}$. In addition, the similar signs of the Cotton effect for $\mathbf{1}$ and $\mathbf{2}$ in the same wavenumber region are attributed to the two chiral coordination polymers having as expected the same absolute configuration. ${ }^{80}$

Powder and Synchrotron X-ray Diffraction. The water molecules in complexes $\mathbf{1}$ and $\mathbf{2}$ can be removed by heating at $100{ }^{\circ} \mathrm{C}$, or simply under vacuum, and exchanged for other organic solvents (for example, methanol or acetonitrile). Compounds $\mathbf{1}$ and $\mathbf{2}$ show very similar thermal behavior, as shown by TG analysis (Figure S5 in the Supporting Information). Between 20 and $140{ }^{\circ} \mathrm{C}$ weight losses of $11.43 \%$ for $\mathbf{1}$ and $8.03 \%$ for 2 are observed. This corresponds to the loss of 6 water molecules (expected 11.38\%) for $\mathbf{1}$ and 24 water molecules for $\mathbf{2}$ (expected $7.89 \%$ ). On loss of solvent molecules the violet crystalline samples of $\mathbf{1}$ and $\mathbf{2}$ transform into deep bluish-purple microcrystalline powders, $\mathbf{1 a}$ and $\mathbf{2 a}$, respectively. We believe that dehydration of compounds $\mathbf{1}$ and $\mathbf{2}$ does not induce a loss of framework structure, as the powder X-ray diffractograms (PXRD) are almost identical to those of $\mathbf{1}$ and $\mathbf{2}$ (Figure S6 in the Supporting Information). Compounds 1a and $\mathbf{2 a}$ are stable in a dry environment, however, once in contact with moisture, their color rapidly reverts to violet. Soaking 1a (the guest-free phase of $\mathbf{1}$ ) in water for one day regenerated the guest-filled phase, i.e. compound 1. The PXRD pattern of this 


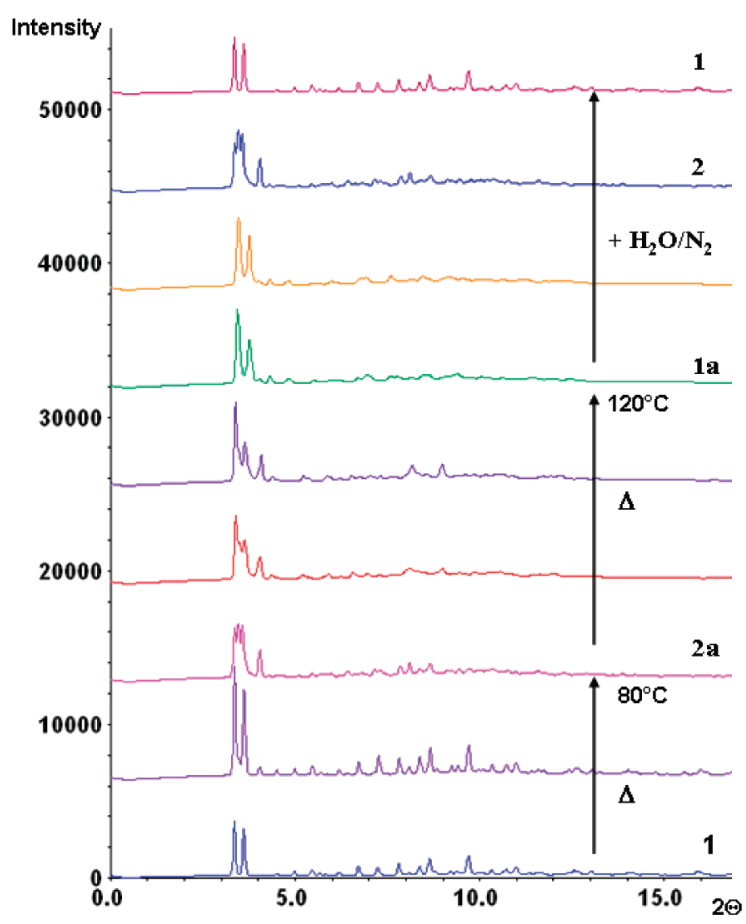

Figure 13. Variable temperature XRPD of complexes 1, showing the transformations during the loss/addition of water molecules.

product is identical to that of the as-synthesized complex $\mathbf{1}$ (Figure S6 in the Supporting Information). This reversible cycle can be repeated many times without loss of crystallinity. Although some dynamic nanoporous framework materials are known, those exhibiting reversible open-dense framework transformations in the crystalline state are still rare. ${ }^{27}$
In the case of $\mathbf{2} \mathbf{a}$ when soaked in water the resulting PXRD shows dramatic changes as compared to the original pattern, that is, it does not revert to $\mathbf{2}$ but transforms into $\mathbf{1}$; the conversion from the triclinic $P 1$ structure to the monoclinic $C 2$ structure having taken place (Figure S6 in the Supporting Information). Further studies using in situ synchrotron radiation PXRD enabled us to follow the behavior of these transformations on heating or on addition of moisture via a stream of $\mathrm{N}_{2}$ saturated with water vapor. While heating the capillary filled with complex $\mathbf{1}$ to $80{ }^{\circ} \mathrm{C}$, the transformation of $\mathbf{1}$ to $\mathbf{2 a}$ was observed (Figure 13). On continued heating to $120{ }^{\circ} \mathrm{C}$ complex 1a was obtained. Hence, it was observed that the formation of $\mathbf{2 a}$ is an intermediate step to obtain 1a (Figure 13). On addition of moisture, via a stream of $\mathrm{N}_{2}$ saturated with water vapor, it was observed that $\mathbf{1 a}$ does not revert to $\mathbf{1}$ immediately but first complex $\mathbf{2}$ is formed, which then transforms to $\mathbf{1}$ on continued wetting of the sample.

The heating of complex 2 to $80{ }^{\circ} \mathrm{C}$ shows almost the same powder pattern, which indicates that the framework is not destroyed and complex $\mathbf{2} \mathbf{a}$ is formed. With continued heating to $120^{\circ} \mathrm{C}$ the final pattern corresponds to that of complex $1 \mathbf{a}$. When passing a stream of $\mathrm{N}_{2}$ saturated with water vapor through an original sample of $\mathbf{2 a}$ (obtained from $\mathbf{2}$ by thermogravimetrical analysis), an almost instantaneous transformation into $\mathbf{1}$ was observed (Figure S7 in the Supporting Information). Because the solvent-exchange processes are carried out in the presence of water vapor (not a condensed liquid), we believe that no dissolution of the framework materials occurs.

The transformations are driven by loss/addition of the water molecules, and the process can be repeated a number of times without loss of crystallinity. The two types of networks reported here show different behavior upon drying, falling within the category of "guest-induced re-formation" frameworks. These

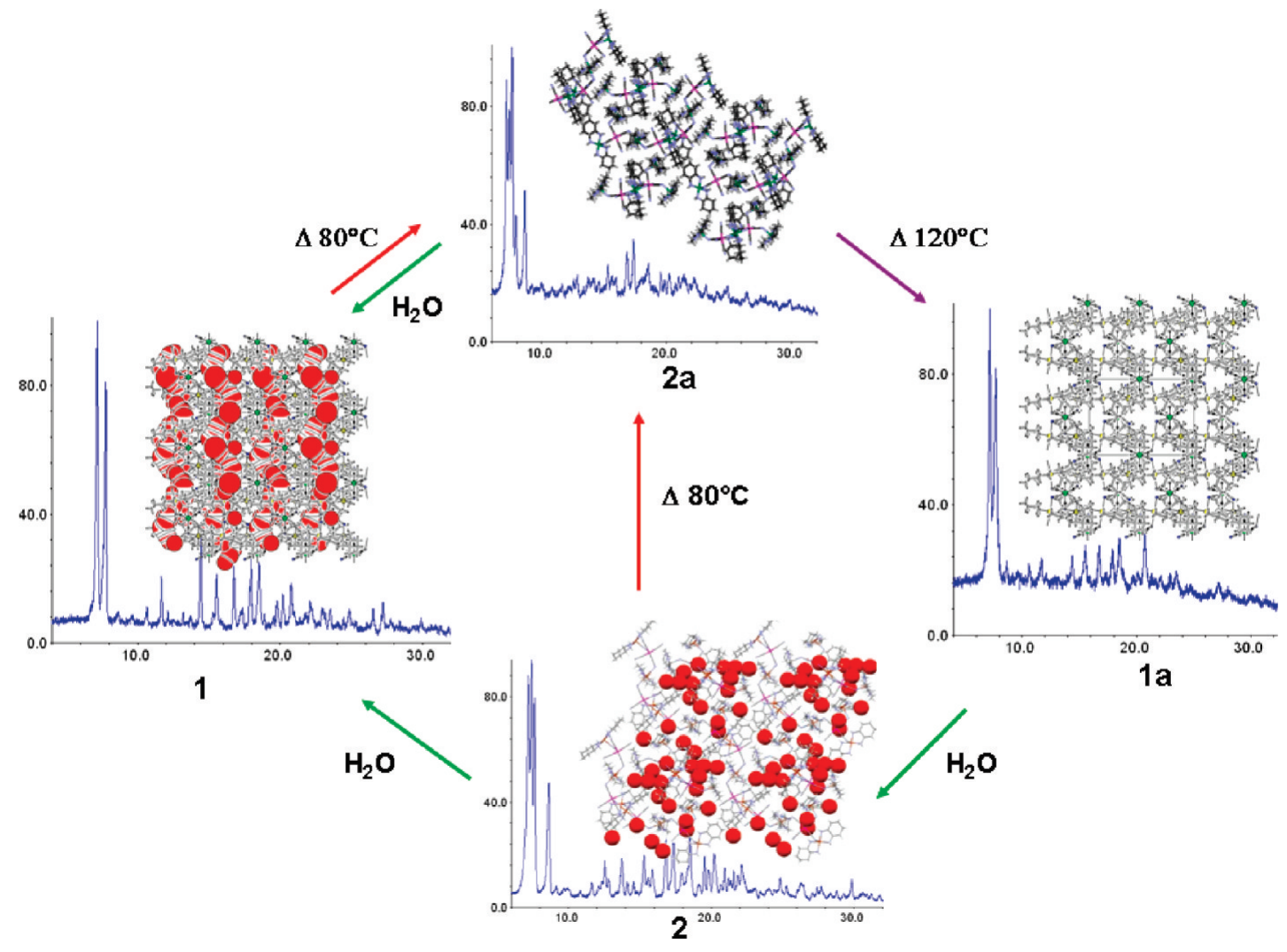

Figure 14. Schematic representation of the reversible transformation processes involving complexes $\mathbf{1}$ and 2. 


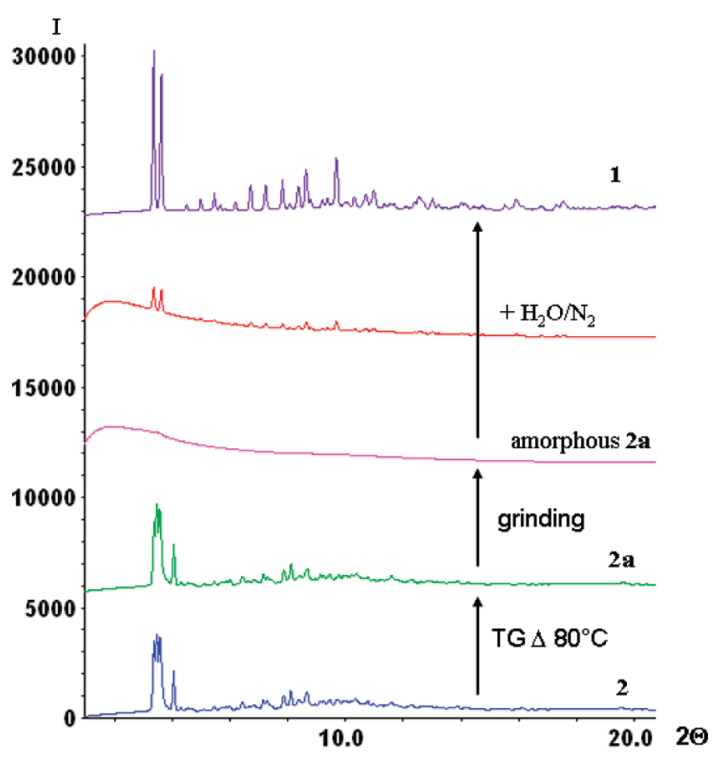

Figure 15. PXRD patterns: blue, a fresh sample of complex 2 at room temperature; green, 2a, was obtained after the heating $\mathbf{2}$ at $80{ }^{\circ} \mathrm{C}$; pink, amorphous $\mathbf{2} \mathbf{a}$ was obtained by grinding a sample of $\mathbf{2} \mathbf{a}$; red, initial diffractogram obtained after passing a stream of nitrogen gas saturated with water vapor through amorphous $\mathbf{2 a}$; violet, the crystallinity of this last sample improved with time to finally resemble the diffractogram for complex $\mathbf{1}$.

reversible transformation processes involving complexes $\mathbf{1}$ and 2 are summarized in Figure 14.

It is interesting to note that, by grinding a sample of $\mathbf{2 a}$ obtained after TG analysis, it became amorphous (Figure 15). However, when passing a stream of $\mathrm{N}_{2}$ saturated with water vapor through a capillary filled with this material, the crystalline structure of complex 1 was regenerated (Figure 15). This transformation associated with water is characterized by a process of "crystal-to-crystal through an amorphous phase".

\section{Conclusions}

In summary, we have successfully constructed two new threedimensional chiral bimetallic cyano-bridged diamondoid frameworks, and demonstrated remarkable structural changes associated with the reversible transformations triggered by dehydration/ rehydration. The removal of the included solvent molecules from these framework materials leads to chiral solids which have permanent porosity and framework integrity. These results show that the synthetic strategy based on cyanide-bridged bimetallic assemblies is advantageous for the formation of flexible nanoporous materials. They show guest-induced structural conversion, that falls within the category of "recoverable collapsing" and "guest-induced re-formation" framework materials.

Acknowledgment. This work was supported by the Swiss National Science Foundation (Grants FN 20-111738 and 20121345).

Supporting Information Available: Additional figures and tables as noted in text and crystallographic information in cif format. This material is available free of charge via the Internet at http://pubs.acs.org.

\section{References}

(1) Batten, S. R.; Neville, S. M.; Turner, D. Coordination Polymers Design, Analysis and Application; Royal Society of Chemistry; Colchester, 2009; Vol. 1.
(2) Tranchemontagne, D. J.; Ni, Z.; O'Keeffe, M.; Yaghi, O. M. Angew. Chem., Int. Ed. 2008, 47 (28), 5136.

(3) Ferey, G. Stud. Surf. Sci. Catal. 2007, 170A, 66

(4) Maji, T. K.; Kitagawa, S. Pure Appl. Chem. 2007, 79 (12), 2155.

(5) Kubota, Y.; Takata, M.; Kobayashi, T. C.; Kitagawa, S. Coord. Chem. Rev. 2007, 251 (21-24), 2510.

(6) Serre, C.; Mellot-Draznieks, C.; Surblé, S.; Audebrand, N.; Filinchuk, Y.; Férey, G. Science 2007, 1828.

(7) Rowsell, J. L. C.; Yaghi, O. M. Microporous Mesoporous Mater. 2004, $73(1-2), 3$.

(8) Rosi, N. L.; Eddaoudi, M.; Kim, J.; O'Keeffe, M.; Yaghi, O. M. CrystEngComm 2002, 4, 401.

(9) Kitagawa, S.; Kitaura, R.; Noro, S.-I. Angew. Chem. 2004, 116, 2388.

(10) Moulton, B.; Zaworotko, M. J. Chem. Rev. 2001, 101, 1629.

(11) Eddaoudi, M.; Moler, D. B.; Li, H.; Chen, B.; Reineke, T. M.; O'Keeffe, M.; Yaghi, O. M. Acc. Chem. Res. 2001, 34, 319.

(12) Fujita, M.; Kwon, Y. J.; Washizu, S.; Ogura, K. J. Am. Chem. Soc. 1994, 116, 1151

(13) Millange, F.; Serre, C.; Guillou, N.; Ferey, G.; Walton, R. I. Angew. Chem., Int. Ed. 2008, 47, 4100.

(14) Ferey, G. Chem. Soc. Rev. 2008, 37 (1), 191.

(15) Latroche, M.; Suble, S.; Serre, C.; Mellot-Draznieks, C.; Llewellyn, P. L.; Lee, J.-H.; Chang, J.-S.; Jhung, S. H.; Ferey, G. Angew. Chem., Int. Ed. 2006, 45, 8227.

(16) Llewellyn, P. L.; Maurin, G.; Devic, T.; Loera-Serna, S.; Rosenbach, N.; Serre, C.; Bourrelly, S.; Horcajada, P.; Filinchuk, Y.; Férey, G. J. Am. Chem. Soc. 2008, 130, 12808.

(17) Banerjee, R.; Phan, A.; Wang, B.; Knobler, C.; Furukawa, H.; O'Keeffe, M.; Yaghi, O. M. Science 2008, 319 (5865), 939.

(18) Xue, M.; Zhu, G.; Ding, H.; Wu, L.; Zhao, X.; Jin, Z.; Qiu, Q. Cryst. Growth Des. 2009, 9 (3), 1481.

(19) Galli, S.; Masciocchi, N.; Tagliabue, G.; Sironi, A.; Navarro, J. A. R.; Salas, J. M.; Mendez-Linan, L.; Domingo, M.; Perez-Mendoza, M.; Barea, E. Chem.-Eur. J. 2008, 14, 9890.

(20) Mueller, U.; Schubert, M. M.; Yaghi, O. M. Handbook of Heterogeneous Catalysis; Wiley-VCH Verlag GmbH \& Co. KGaA: Weinheim, Germany, 2008; Vol. 1.

(21) Rowsell, J. L.; Yaghi, O. M. Angew. Chem., Int. Ed. 2004, 44 (30), 4670.

(22) Janiak, C. Dalton Trans. 2003, 2781.

(23) James, S. L. Chem. Soc. Rev. 2003, 32, 276

(24) Biradha, K.; Hongo, Y.; Fujita, M. Angew. Chem., Int. Ed. 2002, 41, 3392.

(25) Uemura, K.; Kitagawa, S.; Kondo, M.; Fukui, K.; Kitaura, R.; Chang, H.-C.; Mizutani, T. Chem.-Eur. J. 2002, 8, 3587.

(26) Uemura, K.; Kitagawa, S.; Fukui, K.; Saito, K. J. Am. Chem. Soc. 2004, 126, 3817.

(27) Soldatov, D. V.; Ripmeester, J. A.; Shergina, S. I.; Sokolov, I. E.; Zanina, A. S.; Gromilov, S. A.; Dyadin, Y. A. J. Am. Chem. Soc. 1999, 121, 4179 .

(28) Côté, A. P.; Shimizu, G. K. H. Chem.-Eur. J. 2003, 9, 5361.

(29) Uchida, S.; Hashimoto, M.; Mizuno, N. Angew. Chem., Int. Ed. 2002, $41,2814$.

(30) Saied, O.; Maris, T.; Wuest, J. D. J. Am. Chem. Soc. 2003, 125, 14956.

(31) Lu, J. Y.; Babb, A. M. Chem. Commun. 2002, 1340.

(32) Tabares, L. C.; Navarro, J. A. R.; Salas, J. M. J. Am. Chem. Soc. 2001, 123, 383.

(33) Alberti, G.; Murcia-Mascarus, S.; Vivani, R. J. Am. Chem. Soc. 1998, 20, 9291.

(34) Zeng, M.-H.; Feng, X.-L.; Chen, X.-M. Dalton Trans. 2004, 2217.

(35) Min, K. S.; Suh, M. P. Chem.-Eur. J. 2001, 7, 303.

(36) Pan, L.; Woodlock, E. B.; Wang, X. Inorg. Chem. 2000, 39, 4174.

(37) Li, H.; Davis, C. E.; Groy, T. L.; Kelley, D. G.; Yaghi, O. M. J. Am. Chem. Soc. 1998, 120, 2186.

(38) Min, K. S.; Suh, M. P. J. Am. Chem. Soc. 2000, 122, 6834.

(39) Jung, O.-S.; Kim, Y. J.; Lee, Y.-A.; Park, J. K.; Chae, H. K. J. Am. Chem. Soc. 2000, 122, 9921.

(40) Noro, S.-I.; Kitaura, R.; Kondo, M.; Kitagawa, S.; Ishii, T.; Matsuzaka, H.; Yamashita, M. J. Am. Chem. Soc. 2002, 124, 2568.

(41) Beauvais, L. G.; Shores, M. P.; Long, J. R. J. Am. Chem. Soc. 2000, $122,2763$.

(42) Kiritsis, V.; Michaelides, A.; Skoulika, S.; Golhen, S.; Ouahab, L. Inorg. Chem. 1998, 37, 3407.

(43) Larionova, J.; Chavan, S. A.; Yakhmi, J. V.; Froystein, A. G.; Sletten, J.; Sourisseau, C.; Kahn, O. Inorg. Chem. 1997, 36, 6374.

(44) Nossov, A. V.; Soldatov, D. V.; Ripmeester, J. A. J. Am. Chem. Soc. 2001, 123, 3563 .

(45) Verdaguer, M.; Bleuzen, A.; Marvaud, V.; Vaissermann, J.; Seuleiman, M.; Desplanches, C.; Scuiller, A.; Train, C.; Garde, R.; Gelly, G.; 
Lomenech, C.; Rosenman, I.; Veillet, P.; Cartier, C.; Villain, F. Coord. Chem. Rev. 1999, 190-192, 1023.

(46) Ohba, M.; Okawa, H. Coord. Chem. Rev. 2000, 198, 331.

(47) Triki, S.; Sala-Pala, J.; Thétiot, F.; Gomes-Garcia, C. J.; Daran, J.-C. Eur. J. Inorg. Chem. 2006, 185.

(48) Yanai, N.; Kaneko, W.; Yoneda, K.; Ohba, M.; Kitagawa, S. J. Am. Chem. Soc. 2007, 129, 3496.

(49) Eller, S.; Schwarz, P.; Brimah, A. K.; Fischer, R. D. Organometallics 1993, 12, 3232

(50) Eckhardt, R.; Hanika-Heidl, H.; Fischer, R. D. Chem.-Eur. J. 2003, 9, 1795 .

(51) Rüegg, M.; Ludi, A.; Rieder, K. Inorg. Chem. 1971, 10, 1773.

(52) Shek, I. P.-Y.; Yeung, W.-F.; Lau, T.-C.; Zhang, J.; Gao, S.; Szeto, L.; Wong, W.-T. Eur. J. Inorg. Chem. 2005, 364.

(53) Imai, H.; Inoue, K.; Kikuchi, K.; Yoshida, Y.; Ito, M.; Sunahara, T.; Onaka, S. Angew. Chem., Int. Ed. 2004, 43, 5618.

(54) Kimura, T.; Goto, T.; Shintani, H.; Ishizaka, K.; Arima, T.; Tokura, Y. Nature 2003, 426, 55.

(55) Rikken, G. L. J. A.; Raupach, E. Nature 1997, 390, 493.

(56) Yamasaki, Y.; Miyasaka, S.; Kaneko, Y.; He, J.-P.; Arima, T.; Tokura, Y. Phys. Rev. Lett. 2006, 96, 207204.

(57) Kaneko, W.; Kitagawa, S.; Ohba, M. J. Am. Chem. Soc. 2006, 129 (2), 248.

(58) Coronado, E.; Gimenez-Saiz, C.; Martinez-Agudo, J. M.; Nuez, A.; Romero, F. M.; Stoeckli-Evans, H. Polyhedron 2003, 22, 2435.

(59) Imai, H.; Inoue, K.; Ohba, M.; Okawa, H.; Kikuchi, K. Synth. Met. 2003, 137, 919.

(60) Pariya, C.; Liao, F.-L.; Wang, S.-L.; Chung, C.-S. Polyhedron 1998, 17, 547.

(61) Stoe \& Cie. X-Area V1.35 \& X-RED32 V1.31 Software; Stoe \& Cie GmbH: Darmstadt, Germany, 2006.

(62) Sheldrick, G. M. Acta Crystallogr. 2008, A64, 112.
(63) Spek, A. L. Acta Crystallogr. 2009, D65, 148.

(64) Dolomanov, O. V.; Blake, A. J.; Champness, N. R.; Schröder, M. J. Appl. Crystallogr. 2003, 36, 1283.

(65) Pariya, C.; Liao, F.-L.; Wang, S.-L.; Chung, C.-S. Polyhedron 1998, $17,547$.

(66) Mullica, D. F.; Hayward, P. K.; Sappenfield, E. L. Inorg. Chim. Acta 1996, 253, 97.

(67) Bersuker, I. B. Chem. Rev. 2001, 101, 1067.

(68) Hathaway, B. J.; Billing, D. E. Coord. Chem. Rev. 1970, 5, 143.

(69) Shen, L.; Wang, H.-T.; Zhang, Y.-J.; Jin, Z.-M. Acta Crystallogr., Sect. C: Cryst. Struct. Commun. 2004, C60, m180.

(70) Cernak, J.; Lipkowski, J.; Potocnak, I.; Hudak, A. Monatsh. Chem. 2001, 132, 193.

(71) Wells, A. F. Three Dimensional Nets and Polyhedra; John Wiley \& Sons: New York, 1977.

(72) Wells, A. F. Further Studies of Three-Dimensional Nets; ACA Monograph No. 8; American Crystallographic Association: 1979.

(73) O’Keeffe, M. Zeolites 1997, 19, 370.

(74) Sun, X.-R.; Liang, J.-L.; Che, C.-M.; Zhu, N.; Zhangb, X. X.; Gao, S. Chem. Commun. 2002, 2090.

(75) Akitsu, T.; Einaga, Y. Inorg. Chem. 2006, 45, 9826.

(76) Rodriguez-Hernandez, J.; Gomez, A.; Reguera, E. J. Phys. D: Appl. Phys. 2007, 40, 6076.

(77) Darensbourg, M. Y.; Barros, H. L. C. Inorg. Chem. 1979, 18, 3286.

(78) Morpurgo, G. O.; Mosini, V.; Porta, P.; Dessy, G.; Fares, V. J. Chem. Soc., Dalton Trans. 1981, 111.

(79) Dumbar, K. R.; Heintz, R. A. Progress in Inorganic Chemistry; John Wiley \& Sons: New York, 1997.

(80) Coronado, E.; Gomez-Garcia, C. J.; Nuez, A.; Romero, F. M.; Waerenborgh, J. C. Chem. Mater. 2006, 18, 2670.

CG801193R 